\title{
Indikator Risk Based Bank Rating, Kinerja Keuangan dan Perusahaan Perbankan
}

\author{
Ida Bagus Made Bayu Indrawan ${ }^{1}$ \\ Fakultas Ekonomii danl Bisnis \\ Universitas Udayana, Indonesia
}

\author{
I Wayan Pradnyanta Wirasedana ${ }^{2}$ \\ Fakultas Ekonomi dan Bisnis \\ Universitas Udayana, Indonesia
}

Surel : bayuindrawanib@gmail.com

\section{ABSTRAK}

Penelitian memiliki tujuan untuk membuktikan secara empiris mengenai pengaruh Non Performing Loan, Loan to Deposit Ratio, Good Corporate Governance, Net Interest Margin, dan Capital Adequacy Ratio terhadap kinerja keuangan pada perusahaan perbankan terdaftar di BEI. Teori agensi dan Productive theory of credit adalah teori yang digunakan dalam penelitian ini. Populasi penelitian yaitu seluruh Perusahaan Perbankan yang terdaftar di Bursa Efek Indonesia (BEI) tahun 2014-2018 yang berjumlah sebanyak 45 perusahaan. Sampel penelitian berjumlah 30 perusahaan dengan metode non probability sampling dengan teknik purposive sampling. Teknik analisis data yang digunakan yaitu regresi linear berganda. Hasil penelitian diperoleh Non Performing Loan berpengaruh negatif, Loan to Deposit Ratio dan Good Corporate Governance tidak berpengaruh dan signifikan, Net Interest Margin dan Capital Adequacy Ratio berpengaruh positif dan signifikan terhadap kinerja keuangan.

Kata Kunci: Non Performing Loan; Loan to Deposit Ratio; Good Corporate Governance; Net Interest Margin; Capital Adequacy Ratio; Kinerja Keuanngan.

\section{Indicators of Risk Based Bank Ratin, Financial Performance and Banking Companies}

\footnotetext{
ABSTRACT

The research aims to prove empirically the influence of Non-Performing Loans, Loans to Deposit Ratio, Good Corporate Governance, Net Interest Margin, and Capital Adequacy Ratio on financial performance of banking companies listed on the IDX. Agency theory and Productive theory of credit are the theories used in this study. The study population is all Banking Companies listed on the Indonesia Stock Exchange (IDX) in 2014-2018 totaling 45 companies. The research sample of 30 companies with non-probability sampling method with purposive sampling technique. The data analysis technique used is multiple linear regression. The research results obtained by Non Performing Loans are considered negative, Loan to Deposit Ratio and Good Corporate Governance are not approved and are significant, Net Interest Margin and Capital Adequacy Ratio have positive and significant effect on financial performance.

Keywords: $\quad$ Non Performing Loan; Loan to Deposit Ratio; Good Corporate Governance; Net Interest Margin; Capital Adequacy Ratio; Financial Performance.
}

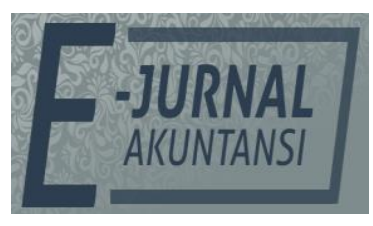

e-ISSN 2302-8556

Vol. 31 No. 3

Denpasar, Maret 2021

Hal. 782-794

DOI:

10.24843/EJA.2021.v31.i03.p20

PENGUTIPAN:

Indrawan, I.B.M.B., \&

Wirasedana, I P. (2021). Indikator Risk Based Bank Rating, Kinerja Keuangan dan Perusahaan Perbankan. E-Jurnal Akuntansi, 31(3), 782-794

RIWAYAT ARTIKEL: Artikel Masuk: 16 Maret 2020 Artikel Diterima: 21 Juli 2020

Artikel dapat diakses : https://ojs.unud.ac.id/index.php/Akuntansi/index 


\section{PENDAHULUAN}

Bank merupakan badan usaha yang menghimpun dana dari masyarakat dalam bentuk simpanan dan menyalurkannya kepada masyarakat dalam bentuk kredit dana tau bentuk-bentuk lainnya. Kinerja bank yang baik diharapkan mampu meningkatkan, meraih, dan memeliharaepercayaan masyarakat maupun investor terhadap suatu bank ataupun sistem perbankan secara menyeluruh. Kinerja keuangan perusahaan dapat diukur dengan Return On Asset (ROA). Return On Asset (ROA) merupakan salah satu rasio yang digunakan untuk mengukur kinerja keuangan perusahaan perbankan dikarenakan ROA dapat memperhitungkan bagaimana kemampuan mengelola manajemen bank dalam memperoleh profitabilitasnya dengan pemanfaatan keseluruhan aset yang dimiliki perusahaan dan ROA dianggap mampu mewakili parameter lainnya.

Berikut grafik return on asset pada perbankan di Indonesia Tahun 2014-2018 yang ditunjukkan pada Gambar 1, sebagai berikut.

Kinerja Keuangan Pada Perbankan Tahun 2014-2018

3

2

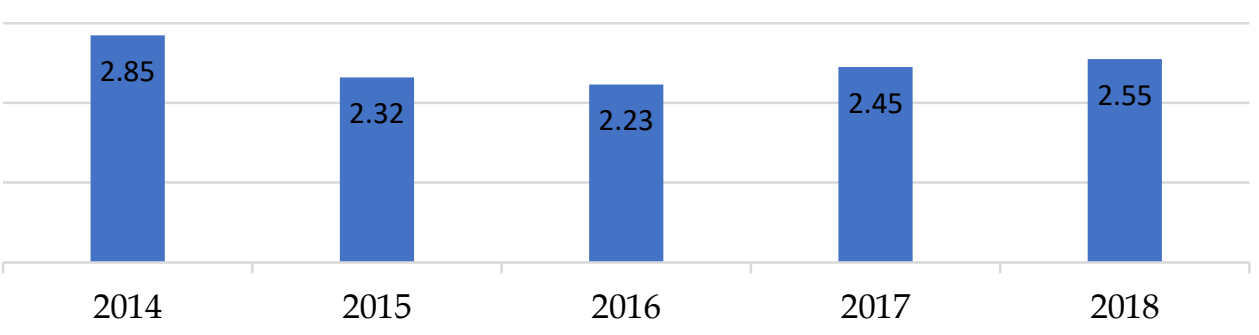

Gambar 1. Grafik Return On Asset pada Perbankan Tahun 2014 - 2018 Sumber: Data Penelitian, 2019

Berdasarkan Gambar 1, grafik Return On Asset (ROA) pada perusahaan perbankan konvensional di Bursa Efek Indonesia mengalami fluktuatif setiap tahunnya dari awal tahun 2014 terjadi penurunan hingga 2016 kemudian mengalami kenaikan secara perlahan di tahun 2017 hingga 2018. Kinerja keuangan terendah terdapat pada tahun 2016 sebesar 2,23\% dan tertinggi pada tahun 2014 sebesar 2,85\%. Berdasarkan fenomena, kinerja keuangan perbankan konvensional di Bursa Efek Indonesia dari tahun 2014-2018 mengalami penurunan, hal ini dapat dipengaruhi oleh beberapa faktor internal dan faktor eksternal. Peraturan Bank Indonesia Nomor 6/10/PBI/ 2004 Tanggal 12 April 2004 dan Surat Edaran Bank Indonesia No.6/23/DPNP tentang Sistem Penilaian Tingkat Kesehatan Bank Umum, Penilaian tingkat kesehatan Bank mencakup penilaian terhadap faktorfaktor CAMELS yang terdiri dari Capital, Asset, Management, Earnings, Liquidity, dan Sensitivity to Market Risk. Kemudian Bank Indonesia kembali menerbitkan peraturan baru dengan menggunakan Risk Based Bank Rating pada tahun 2011. Konsep RBBR mewajibkan bank memelihara dan/atau meningkatkan tingkat kesehatan bank dengan menerapkan prinsip kehati-hatian dan manajemen risiko dalam melaksanakan kegiatan usaha. Berdasarkan peraturan Bank Indonesia No. 13/1/PBI/2011 tentang penilaian kesehatan Bank Umum. Faktor-faktor yang digunakan dalam penerapan penilaian tingkat kesehatan bank terdiri dari Risk Profil, Good Corporate Governance, Earnings, dan Capital. 
Risiko kredit merupakan penyebab utama kegagalan bank. Risiko kredit pada penelitian ini diukur dengan Non Performing Loan (NPL). Besarnya persentase NPL haruslah menjadi perhatian pihak manajemen karena kredit bermasalah yang semakin meningkat dapat membahayakan kesehatan bank tersebut (Septiani \& Lestari, 2016). Penelitian yang dilakukan oleh Negara \& Sujana (2014), Putrianingsih \& Yulianto (2016), Satriawan \& Sudiartha (2013), Yudiartini \& Dharmadiaksa (2016), serta Suwandi \& Oetomo (2017) menghasilkan hasil penelitian NPL berpengaruh negatif terhadap kinerja keuangan pada perusahaan perbankan.

Sebuah bank memiliki kualitas aset yang baik, pendapatan yang kuat dan modal yang cukup, mungkin gagal jika tidak mempertahankan likuiditas yang memadai (Crowe, 2009). Risiko yang akan muncul berkaitan dengan masalah tersebut adalah risiko likuiditas. Dalam penelitian ini risiko likuiditas diukur dengan Loan to Deposit Ratio (LDR). LDR digunakan untuk mengukur kemampuan bank dalam membayar kewajibannya kepada deposan serta dapat memenuhi permintaan kredit yang diajukan. Hasil penelitian yang dilakukan oleh Indrawati \& Anan (2014) dan Satriawan \& Sudiartha (2013) menyimpulkan bahwa LDR berpengaruh positif terhadap kinerja keuangan, hal ini sejalan dengan penelitian Olweny \& Shipo (2011), Widati (2012), Porawouw et al. (2014), serta Suwandi \& Oetomo (2017).

Perusahaan yang menerapkan praktik GCG pada umumnya dapat meningkatkan modal perusahaannya lebih mudah dan dalam jangka panjang akan lebih menguntungkan serta kompetitif dibandingkan perusahaan yang memiliki tata kelola perusahaan yang buruk (Todorovic, 2013). Corporate governance merupakan salah satu mekanisme pengendalian internal paling penting dari masalah lembaga dalam mengurangi salah satu dampak dari hubungan keagenan (Clemente \& Labat, 2009). Investor akan melakukan investasi yang lebih besar untuk perusahaan yang mempunyai tata kelola yang baik daripada perusahaan yang memiliki predikat yang buruk pada tata kelola perusahaannya (Harsalim, 2017). Pada penelitian ini, GCG diwakili oleh Corporate Governance Perseption Index (CGPI) yang telah disurvei oleh IICG dimana Penelitian mengenai pengaruh GCG terhadap kinerja keuangan sudah dilakukan oleh beberapa peneliti. Penelitian yang dilakukan Adebayo et al., (2014), Astutik \& Dzajuli (2014), menunjukan GCG berpengaruh positif terhadap kinerja keuangan.

Kemampuan bank dalam mengelola aktiva produktif sehingga menghasilkan laba bersih. Alat ukur earnings pada penelitian ini menggunakan Net Interest Margin (NIM). NIM diatur oleh bank untuk menutupi semua resiko dan semua biaya intermediasinya (Srdan \& Ognjen, 2014). Semakin meningkatnya pendapatan bunga atas aktiva produktif berarti semakin besar rasio NIM, meningkatnya pendapatan bunga dapat meningkatkan profitabilitas bank dan kinerja keuangan akan meningkat.. Penjelasan diatas sejalan dengan penelitian yang dilakukan oleh penelitian yang dilakukan oleh Sudiyanto \& Setyowati (2012) yang menjelaskan bahwa NIM (Net Interest Margin) berpengaruh positif terhadap ROA (Return On Asset).

Dincer et al. (2011) menyatakan bahwa kecukupan modal menunjukan pengukuran kekuatan bank. Dalam penelitian ini capital diukur menggunakan Capital Adequacy Ratio (CAR). Rasio CAR yang semakin meningkat menunjukkan 
kemampuan bank yang semakin baik dalam mempertahankan kecukupan modalnya untuk menjaga kualitas bank agar tetap sehat sehingga meminimalisir terjadinya risiko sehingga dapat meningkatkan kinerja keuangan. Berdasarkan penelitian yang dilakukan oleh Victoria \& Erawati (2015), Widati (2012), Olalekan \& Adeyinka (2013), , Wantera \& Mertha (2015), serta Olaoye et al. (2015) menyimpulkan bahwa CAR (Capital Adequacy Ratio) berpengaruh terhadap kinerja keuangan yang diukur dengan rasio ROA (Return On Asset).

Teori agensi bahwa adanya hubungan kontraktual antara prinsipal dan agen. Menurut Halisa et al. (2017) bank yang seharusnya menjalankan amanah pemilik dana (deposan) untuk menggunakan dana tersebut secara hati-hati, namun tidak sedikit manajemen bank cenderung meningkatkan kesejahteraan mereka sendiri dan bertindak atas kepentingan sendiri yaitu dengan pengambilan keputusan yang tidak hati-hati, baik itu keputusan dalam menyalurkan kredit secara langsung ke debitur ataupun memilih menyalurkan dana ke anak perusahaannya. Saat tidak terjadi keselarasan insentif, maka akan terjadi konflik kepentingan conflict interest yang dapat berupa keputusan manajemen bank untuk melakukan investasi yang berisiko tinggi karena menginginkan keuntungan pribadi yang sebesar-besarnya, terlebih lagi jika hal tersebut terjadi pada bank dengan ukuran perusahaan cukup besar yang memiliki kemungkinan untuk menghasilkan keuntungan lebih besar, sehingga muncullah agency problem yang akan menimbulakn agency cost untuk mengurangi adanya agency problem.

Berdasarkan uraian, adapun rumusan masalah penelitian, Bagaimana pengaruh Non Performing Loan, Loan to Deposit Ratio, Good Corporate Governance, Net Interest Margin, dan Capital Adequacy Ratio terhadap kinerja keuangan pada perusahaan perbankan yang terdaftar di BEI. Tujuan penelitian untuk mengetahui bukti empiris pengaruh Non Performing Loan, Loan to Deposit Ratio, Good Corporate Governance, Net Interest Margin, dan Capital Adequacy Ratio terhadap kinerja keuangan pada perusahaan perbankan yang terdaftar di BEI. Manfaat teoretis diharapkan dapat memberikan tambahan informasi mengenai variabel penelitian. Manfaat praktis diharapkan dapat memberikan tambahan informasi serta pertimbangan pengambilan keputusan bagi pihak yang berkepntingan.

Jensen \& Meckling (1976) mendefinisikan teori keagenan sebagai hubungan kontraktual antara prinsipal dan agen. Pihak prinsipal adalah pihak yang memberikan mandat kepada pihak lain yaitu agen untuk melakukan semua kegiatan atas nama prinsipal dalam kapasitasnya sebagai pengambil keputusan. Secara garis besar teori agensi dikelompokkan menjadi dua, yaitu positive agency research dan principal agent research. Positve agent research memfokuskan pada identifikasi situasi dimana agen dan prinsipal mempunyai tujuan yang bertentangan dan mekanisme pengendalian yang terbatas hanya menjaga perilaku self serving agen. Sementara itu principal agent research memfokuskan pada kontrak optimal antara perilaku dan hasilnya, secara garis besar penekanan pada hubungan principal dan agent.

Productive Theory of Credit ini menjelaskan tentang dasar-dasar yang digunakan manajemen untuk mengambil keputusan sumber pendanaan bagi perusahaan. Apabila dalam situasi ekonomi yang sedang tidak baik, kredit modal kerja, yang pelunasannya berasal dari arus kas nasabah debitur, akan menjadi tidak lancar. Standar kecukupan modal diperlukan agar dapat menjamin 
keunikan pelayanan bank, melindungi bank dari kegagalan (risiko) seperti risiko kredit serta menjamin berkelanjutan bank. Teori menyatakan bahwa bank-bank hanya akan memberikan kredit kepada nasabah yang telah disetujui oleh pihak bersangkutan, karena kredit sangat berpengaruh dengan kesehatan bank.

Bank harus mempunyai dana agar dapat memberikan kredit kapada masyarakat dalam memberikan kredit. Manajemen perusahaan seharusnya mengetahui kondisi perusahaan mengenai kredit yang diberikan, hal ini berkaitan dengan agency theory. Risiko kredit merupakan suatu risiko akibat kegagalan atau ketidakmampuan nasabah dalam mengembalikan jumlah pinjaman yang diterima beserta bunganya, sesuai jangka waktu yang telah ditentukan. Menurut penelitian Satriawan \& Sudiartha (2013), bahwa NPL berpengaruh negatif terhadap kinerja keuangan sejalan dengan penelitian yang dilakukan oleh Negara \& Sujana (2014), Putrianingsih \& Yulianto (2016), Yudiartini \& Dharmadiaksa (2016), Suwandi \& Oetomo (2017) yang juga menunjukkan bahwa NPL berpengaruh negatif terhadap kinerja keuangan. Berdasarkan penjelasan dan penelitian terdahulu maka hipotesis yang dapat ditarik sebagai berikut.

$\mathrm{H}_{1}$ : Non performing loan berpengaruh negatif terhadap kinerja keuangan.

Risiko likuiditas terjadi karena penyaluran dana dalam bentuk kredit lebih besar jika dibandingkan dengan simpanan masyarakat atau dana pihak ketiga pada suatu bank sehingga menimbulkan risiko yang harus ditanggung oleh bank, apalagi jika kredit yang disalurkan mengalami kegagalan maka bank akan kesulitan untuk mengembalikan dana masyarakat yang dititipkan di bank. Menurut penelitian yang dilakukan oleh Indrawati \& Anan (2014) menjelaskan bahwa LDR berpengaruh positif terhadap kinerja keuangan, penelitian sejalan dengan penelitian Olweny \& Shipo (2011), Widati (2012), Satriawan \& Sudiartha (2013), Porawouw et al. (2014), Suwandi \& Oetomo (2017). Berdasarkan penjelasan dan penelitian sebelumnya, maka hipotesis yang dapat ditarik sebagai berikut. $\mathrm{H}_{2}$ : Loan to deposit ratio berpengaruh positif terhadap kinerja keuangan.

Teori agensi menyatakan bahwa manajemen perusahaan lebih mengetahui bagaiamana kondisi perusahaan dibandingkan dengan investor. Manajemen perusahaan perlu menerapkan good corporate governance untuk mencapai tujuan perusahaan. Good corporate governance yang merupakan tata kelola perusahaan merupakan salah satu faktor yang dapat mempengaruhi kinerja perusahaan. Penelitian dari Astutik \& Dzajuli (2014), Adebayo et al. (2014) menunjukan bahwa Good Corporate Governance berpengaruh positif terhadap kinerja keuangan. Perusahaan yang menerapkan tata kelola perusahaan yang baikdapat meningkatkan kepercayaan investor yang akan membuat kinerja keuangan meningkat. Berdasarkan penjelasan diatas dan penelitian sebelumnya, maka hipotesis yang dapat ditarik sebagai berikut.

$\mathrm{H}_{3}$ : Good corporate governance berpengaruh positif terhadap kinerja keuangan.

Menurut Kasmir (2014:196), rentabilitas merupakan rasio untuk menilai kemampuan perusahaan dalam mencari keuntungan. Pentingnya peran manajemen dalam mencari keuntungan perusahaan agar keuntungan perusahaan dapat dicapai. Pendapatan diperoleh dari bunga yang diterima dari pinjaman yang diberikan dikurangi dengan biaya bunga dari sumber dana yang dikumpulkan. Hasil penelitian yang dilakukan oleh Sudiyanto \& Setyowati (2012) yang menjelaskan bahwa NIM (Net Interest Margin) berpengaruh terhadap kinerja 
keuangan. Berdasarkan penjelasan dan penelitian sebelumnya, maka hipotesis yang dapat ditarik sebagai berikut.

$\mathrm{H}_{4}$ : Net interest margin berpengaruh positif terhadap kinerja keuangan.

Permodalan adalah aspek kecukupan modal yang menunjukkan kemampuan bank dalam mempertahankan modal yang mencukupi dan kemampuan manajemen bank dalam mengidentifikasi, mengawasi dan mengontrol risiko-risiko yang timbul yang dapat berpengaruh terhadap besarnya modal bank. Berdasarkan penelitian yang dilakukan oleh Widati (2012), Olalekan \& Adeyinka (2013), Victoria \& Erawati (2015), Wantera \& Mertha (2015) menjelaskan bahwa CAR (Capital Adequacy Ratio) berpengaruh terhadap kinerja keuangan yang diukur dengan rasio ROA (Return On Asset). Berdasarkan penjelasan dan penelitian sebelumnya, maka hipotesis yang dapat ditarik adalah. $\mathrm{H}_{5}$ : Capital adequecy ratio berpengaruh positif terhadap kinerja keuangan.

\section{METODE PENELITIAN}

Populasi yang dimaksud dalam penelitian ini adalah seluruh Perusahaan Perbankan yang terdaftar di Bursa Efek Indonesia (BEI) tahun 2014-2018. Penelitian ini melalui pendekatan yang berbentuk asosiatif dengan jenis data kuantitatif. Sumber data sekunder dengan metode observasi dengan Laporan keuangan tahunan Perusahaan Perbankan yang terdaftar di Bursa Efek Indonesia tahun 2014-2018 yang diperoleh melalui website www.idx.co.id dan nilai pemeringkatan komposit corporate governance perception index (CGPI) 2014-2018 yang dikeluarkan oleh lembaga riset independen IICG.

Kinerja perusahaan merupakan suatu gambaran tentang kondisi keuangan suatu perusahaan yang dianalisis dengan alat-alat analisis keuangan, sehingga dapat diketahui mengenai baik buruknya keadaan keuangan suatu perusahaan yang mencerminkan prestasi kerja dalam periode tertentu. Bank Indonesia dalam Surat Edaran Bank Indonesia No. 06/23/DPNP tanggal 31 Mei 2004 mengemukakan terdapat rasio yang digunakan sebagai parameter dari kinerja keuangan bank yaitu Return On Asset (ROA). Perhitungan return on asset menurut Kasmir (2014) sebagai berikut.

$R O A=\frac{\text { Laba Bersih }}{\text { Rata-rata Total Aset }} \times 100 \%$.

Profil risiko yang wajib dinilai secara inheren terdiri atas delapan jenis risiko, yaitu risiko kredit, risiko pasar, risiko operasional, risiko likuiditas, risiko hukum, risiko stratejik, risiko kepatuhan, dan risiko reputasi. Perhitungan rasio Non Performing Loan (NPL) berdasarkan Surat Edaran Bank Indonesia No.13/24/DPNP tanggal 25 Oktober 2011.

$N P L=\frac{\text { Kredit Bermasalah }}{\text { Total Kredit }} \times 100 \%$

Perhitungan rasio Loan to Deposit Ratio (LDR) berdasarkan Surat Edaran Bank Indonesia Nomor 6/23/DPNP tanggal 31 Mei 2004.

$L D R=\frac{\text { kredit }}{\text { Total Kredit }} \times 100 \%$.

Good corporate governance merupakan suatu tatanan pengelolaan berupa struktur, sistem, dan proses berbagai upaya untuk memberikan nilai tambah perusahaan secara berkesinambungan dengan menekankan pentingnya kesetaraan, transparansi, akuntabilitas, kemandirian, dan responsibilitas. ariabel 
GCG dalam penelitian ini diukur dengan menggunakan instrumen yang dikembangkan oleh Indonesian Institute of Corporate Governance (IICG) berupa Corporate Governance Perception Index (CGPI).

Perhitungan rentabilitas (earnings) menggunakan rasio NIM, karena pendapatan bank diperoleh dari pendapatan bunga bersih terhadap rata-rata produktif yang akan menentukan besarnya laba bersih. Berdasarkan Surat Edaran Bank Indonesia No.13/24/DPNP dan klasifikasi peringkat komposit berdasarkan peraturan Bank Indonesia adalah sebagai berikut.

$N I M=\frac{\text { Pendapatan Bunga Bersih }}{\text { Rata-rata Aset Produktif }} \times 100 \%$

Penilaian terhadap faktor permodalan meliputi penilaian terhadap tingkat kecukupan permodalan dan pengelolaan permodalan pada suatu bank. Penilaian untuk faktor permodalan (capital) menggunakan Capital Adequacy Ratio (CAR) berdasarkan Surat Edaran Bank Indonesia No.13/24/DPNP dan klasifikasi peringkat kompositnya berdasarkan peraturan Bank Indonesia adalah sebagai berikut.

$C A R=\frac{\text { Modal }}{A T M R} \times 100 \%$

\section{HASIL DAN PEMBAHASAN}

Perusahaan perbankan dalam penelitian ini dipilih menggunakan teknik purposive sampling sesuai dengan kriteria yang telah ditetapkan, dan diperoleh sebanyak 98 sampel perusahaan Proses penyeleksian sampel dalam penelitian ini ditunjukkan pada Tabel 1, berikut.

\section{Tabel 1. Kriteria Pemilihan Sampel}

\begin{tabular}{llc}
\hline No. & \multicolumn{1}{c}{ Kriteria } & Jumlah \\
\hline 1 & Perusahaan perbankan yang terdaftar di Bursa Efek Indonesia & \\
& Periode 2014-2018 & 45 \\
2 & Perusahaan perbankan yang tidak mempublikasikan laporan & $(12)$ \\
3 & keuangan secara berturut-turut selama periode 2014-2018 & $(3)$ \\
Jumlah perusahan yang terpilih dijadikan sampel & 30 \\
Jumlah tahun pengamatan penelitian & 5 \\
Total sampel dalam lima tahun penelitian & 150 \\
\hline
\end{tabular}

Sumber: Data Penelitian, 2020

Berdasarkan Tabel 1, dapat diketahui bahwa perusahaan perbankan yang tidak mempulikasikan laporan keuangan secara berturut-turut selama tahun 20142018 sebanyak 12 perusahaan yaitu perusahaan AGRO, ARTO, BABP, BBNP, BCIC, BEKS, BGTG, BINA, BRIS, BTPS, DNAR, MCOR. Selanjutnya terdapat 3 perusahaan yang mengandung data outlier yaitu perusahaan BSWD, MAYA dan NAGA. Berdasarkan kriteria pemilihan sampel tersebut maka perusahan yang terpilih dijadikan sampel adalah sebanyak 30 perusahaan, dengan 5 tahun pengamatan penelitian, maka diperoleh total sampel selama tiga tahun penelitian sebanyak 150.

Kinerja keuangan $(\mathrm{Y})$ memiliki nilai rata-rata ROA sebesar 1,595 mendekati nilai maksimal sebesar 12,37. Nilai standar deviasi atas kinerja keuangan sebesar 2,31997 nilai ini lebih kecil dibandingkan nilai rata-rata. Nilai minimum ROA 
sebesar -10,77 dimiliki oleh Bank Panin Dubai Syariah Tbk pada tahun 2017. Non Performing Loan (X1) memiliki nilai rata-rata sebesar 1,575 mengarah pada nilai minimum sebesar 0,00. Nilai standar deviasi Non Performing Loan sebesar 1,345 lebih kecil daripada nilai rata-ratanya. Loan to Deposit Ratio (X2) memiliki nilai ratarata sebesar 86,067 mengarah pada nilai maksimum sebesar 112,54. Nilai standar deviasi Loan to Deposit Ratio sebesar 12,098 lebih kecil daripada nilai rata-ratanya. Net Interest Margin (X3) memiliki nilai rata-rata sebesar 5,207 mendekati nilai maksimum sebesar 13,61. Nilai standar deviasi Net Interest Margin sebesar 2,521 lebih tinggi daripada nilai rata-ratanya. Capital Adequacy Ratio (X4) memiliki nilai rata-rata sebesar 20,314 mengarah pada nilai maksimum sebesar 48,38. Nilai standar deviasi Capital Adequacy Ratio sebesar 5,228 lebih kecil daripada nilai rataratanya. Good Corporate Governance (X5) memiliki nilai rata-rata CGPI sebesar 80,585 mendekati nilai maksimal sebesar 93,41. Nilai deviasi standar Good Corporate Governance sebesar 5,547 lebih rendah dibandingkan dengan nilai rata rata.

Tabel 2. Hasil Statistik Deskriptif

\begin{tabular}{lrrrrr}
\hline & N & Minimum & Maximum & \multicolumn{1}{c}{ Mean } & Std. Deviation \\
\hline ROA & 150 & $-10,77$ & 12,37 & 1,5955 & 2,31997 \\
NPL & 150 & 0,00 & 9,92 & 1,5755 & 1,34513 \\
LDR & 150 & 50,61 & 112,54 & 86,0676 & 12,09803 \\
NIM & 150 & $-11,57$ & 13,61 & 5,2079 & 2,52115 \\
CAR & 150 & 10,53 & 48,38 & 20,3143 & 5,22857 \\
CGPI & 150 & 69,05 & 93,41 & 80,5857 & 5,54725 \\
Valid N (listwise) & 150 & & & & \\
\hline
\end{tabular}

Sumber: Data Penelitian, 2020

Hasil uji normalitas nilai Asymp. Sig (2-tailed) sebesar 0,058 yang lebih besar daripada 0,05 . Hal ini berarti bahwa model persamaan regresi dalam penelitian ini dengan menggunakan variabel dependen kinerja keuangan sudah berdistribusi secara normal. Hasil uji multikolinearitas menunjukkan bahwa nilai tolerance pada masing-masing variabel lebih besar dari $10 \%(0,1)$, demikian pula dengan nilai VIF masing-masing variabel yang lebih kecil dari 10. Hal ini menandakan bahwa pada persamaan regresi linier berganda dengan variabel dependen kinerja keuangan ini tidak terdapat kolerasi antar variabel bebas sehingga persamaan ini bebas dari gejala multikolinearitas.

Hasil uji autokorelasi menunjukkan menunjukkan bahwa besarnya nilai Aymp.Sig (2-tailed) pada uji Run Test sebesar 0,204 yang lebih dari 0,05, maka dapat disimpulkan bahwa tidak terdapat autokorelasi antar nilai residual. Hasil uji heteroskedastisitas menunjukkan bahwa nilai signifikansi untuk variabel Non Performing Loan (X1) sebesar 0,199, untuk variabel Loan to Deposit Ratio (X2) sebesar 0,868, untuk variabel Good Corporate Governance (X3) sebesar 0,061, untuk variabel Net Interest Margin (X4) sebesar 0,888 dan Capital Adequacy Ratio (X5) sebesar 0,058. Nilai tersebut menunjukkan bahwa masing-masing variabel memiliki signifikansi yang lebih besar dari 0,05. Hal ini menunjukkan bahwa model regresi dalam penelitian ini bebas dari gejala heteroskedastisitas.

Dari hasil analisis regresi linear berganda pada Tabel 3, dapat dibuat persamaan sebagai berikut. 


$$
Y=-6,049-0,464 X 1+0,013 X 2+0,040 X 3+0,532 X 4+0,064 X 5+\varepsilon
$$

Tabel 3. Hasil Analisis Regresi Linear Berganda

\begin{tabular}{|c|c|c|c|c|c|c|}
\hline \multirow{3}{*}{\multicolumn{2}{|c|}{ Model }} & & & \multirow{2}{*}{\multicolumn{3}{|c|}{$\begin{array}{c}\text { Standardized } \\
\text { Coefficients }\end{array}$}} \\
\hline & & \multicolumn{2}{|c|}{ Unstandardized Coefficients } & & \multirow[b]{2}{*}{$\mathrm{t}$} & \multirow[b]{2}{*}{ Sig. } \\
\hline & & B & Std. Error & Beta & & \\
\hline \multirow[t]{6}{*}{1} & (Constant) & $-6,049$ & 2,226 & & $-2,717$ & 0,007 \\
\hline & NPL & $-0,464$ & 0,095 & $-0,269$ & $-4,860$ & 0,000 \\
\hline & LDR & 0,013 & 0,010 & 0,067 & 1,286 & 0,200 \\
\hline & CGPI & 0,040 & 0,022 & 0,094 & 1,820 & 0,071 \\
\hline & NIM & 0,532 & 0,053 & 0,578 & 9,978 & 0,000 \\
\hline & CAR & 0,064 & 0,026 & 0,145 & 2,459 & 0,015 \\
\hline
\end{tabular}

Sumber: Data Penelitian, 2020

Nilai konstanta (a) sebesar $-6,049$ berarti apabila Non Performing Loan $\left(\mathrm{X}_{1}\right)$, Loan to Deposit Ratio $\left(\mathrm{X}_{2}\right)$, Good Corporate Governance $\left(\mathrm{X}_{3}\right)$, Net Interest Margin $\left(\mathrm{X}_{4}\right)$ dan Capital Adequacy Ratio $\left(\mathrm{X}_{5}\right)$ bernilai 0, maka kinerja keuangan adalah sebesar 6,049. Nilai koefisien regresi Non Performing Loan $\left(\beta_{1}\right)$ sebesar $-0,464$ berarti apabila Non Performing Loan meningkat sebesar 1 satuan dengan anggapan variabel lainnya konstan, maka kinerja keuangan menurun sebesar -0,464 satuan. Nilai koefisien regresi Loan to Deposit Ratio $\left(\beta_{2}\right)$ sebesar 0,013 berarti apabila Loan to Deposit Ratio meningkat sebesar 1 satuan dengan anggapan variabel lainnya konstan, maka kinerja keuangan akan meningkat sebesar 0,013 satuan. Nilai koefisien regresi Good Corporate Governance $\left(\beta_{3}\right)$ sebesar 0,040 berarti apabila Good Corporate Governance meningkat sebesar 1 satuan dengan anggapan variabel lainnya konstan, maka kinerja keuangan akan meningkat sebesar 0,040 satuan. Nilai koefisien regresi Net Interest Margin $\left(\beta_{4}\right)$ sebesar 0,532 berarti apabila Net Interest Margin meningkat sebesar 1 satuan dengan anggapan variabel lainnya konstan, maka kinerja keuangan akan meningkat sebesar 0,532 satuan. Nilai koefisien regresi Capital Adequacy Ratio $\left(\beta_{5}\right)$ sebesar 0,064 berarti apabila Capital Adequacy Ratio meningkat sebesar 1 satuan dengan anggapan variabel lainnya konstan, maka kinerja keuangan akan meningkat sebesar 0,064 satuan.

Hipotesis pertama menyatakan bahwa Non Performing Loan berpengaruh negatif pada kinerja keuangan. Berdasarkan hasil uji $t$ analisis regresi linier berganda pada Tabel 3, menunjukkan koefisien regresi Non Performing Loan adalah $-0,464$ mengindikasikan bahwa $\mathrm{H}_{1}$ diterima. Hasil penelitian ini menunjukkan bahwa Non Performing Loan yang semakin tinggi menunjukkan semakin buruknya kualitas kredit bank yang menyebabkan jumlah kredit bermasalah semakin besar. Temuan ini sesuai dengan agency theory yang menjelaskan bahwa Bank harus mempunyai dana agar dapat memberikan kredit kapada masyarakat dalam memberikan kredit. Manajemen perusahaan seharusnya mengetahui kondisi perusahaan mengenai kredit yang diberikan. Berdasarkan teori agency tersebut, risiko kredit merupakan suatu risiko akibat kegagalan atau ketidakmampuan nasabah dalam mengembalikan jumlah pinjaman yang diterima beserta bunganya, sesuai jangka waktu yang telah ditentukan. Risiko kredit pada penelitian ini diukur dengan Non Performing Loan (NPL). Semakin tinggi rasio ini menunjukkan semakin buruknya kualitas kredit bank yang menyebabkan jumlah kredit bermasalah semakin besar. Temuan ini sejalan dengan penelitian Satriawan \& Sudiartha (2013) yang menyatakan bahwa Non Performing Loan berpengaruh 
negatif terhadap kinerja keuangan, karena semakin besar Non Performing Loan yang didapatkan oleh perusahaan maka akan menurunkan kinerja keuangan perusahaan. Hasil penelitian ini juga mendukung temuan penelitian Negara \& Sujana (2014), Putrianingsih \& Yulianto (2016), Yudiartini \& Dharmadiaksa (2016), Suwandi \& Oetomo (2017) yang juga menunjukkan bahwa NPL berpengaruh negatif terhadap kinerja keuangan. Kondisi ini menunjukkan bahwa semakin tinggi besarnya Non Performing Loan yang dihasilkan, maka semakin rendah kinerja keuangannya.

Hipotesis kedua menyatakan bahwa Loan to Deposit Ratio berpengaruh positif pada kinerja keuangan. Berdasarkan hasil uji $t$ analisis regresi linier berganda pada Tabel 3, menunjukkan koefisien regresi Loan to Deposit Ratio adalah 0,013 dengan tingkat signifikansi sebesar 0,200 yang lebih dari 0,050. mengindikasikan bahwa $\mathrm{H}_{2}$ ditolak. Hasil penelitian ini menunjukkan bahwa semakin tinggi atau besar dana dari pihak ketiga yang dapat dihimpun oleh perbankan dan disalurkan dalam bentuk kredit secara tepat, efesien dan hati-hati maka akan dapat meningkatkan pendapatan perbankan karena semakin tinggi LDR semakin besar juga untuk mencapai ROA. Hasil penelitian ini sejalan dengan temuan Sugiantari \& Dana (2019) yang menjelaskan bahwa LDR berpengaruh positif dan tidak signifikan terhadap ROA. Hasil penelitian ini juga mendukung temuan penelitian Isramiarsyh (2016) yang menyatakan bahwa Loan to Deposit Ratio (LDR) berpengaruh positif dan tidak signifikan terhadap kinerja keuangan (ROA).

Hipotesis ketiga menyatakan bahwa Good Corporate Governance berpengaruh positif dan signifikan pada kinerja keuangan. Berdasarkan hasil uji $t$ analisis regresi linier berganda pada Tabel 3, memperoleh nilai koefisien regresi Good Corporate Governance sebesar 0,040 dengan tingkat signifikansi sebesar 0,071 yang kurang dari 0,05 mengindikasikan bahwa $\mathrm{H}_{3}$ ditolak. Good Corporate Governance memiliki arah hubungan yang positif pada kinerja keuangan. Hasil penelitian ini sesuai dengan Teori agensi. Menurut Teori agensi, manajemen perusahaan lebih mengetahui bagaiamana kondisi perusahaan dibandingkan dengan investor. Manajemen perusahaan perlu menerapkan good corporate governance untuk mencapai tujuan perusahaan. Good corporate governance yang merupakan tata kelola perusahaan merupakan salah satu faktor yang dapat mempengaruhi kinerja perusahaan. Hasil penelitian ini sesuai dengan hasil penelitian yang ditemukan oleh Widyastuti (2017), yang menyatakan bahwa Good Corporate Governance tidak berpengaruh signifikan terhadap kinerja keuangan. Hasil penelitian ini juga mendukung temuan penelitian Sejati et al., (2018) menunjukan bahwa Good Corporate Governance tidak berpengaruh signifikan terhadap kinerja keuangan.

Hipotesis keempat menyatakan bahwa Net Interest Margin tidak berpengaruh signifikan pada kinerja keuangan. Berdasarkan hasil uji $\mathrm{t}$ analisis regresi linier berganda pada Tabel 3, menunjukkan koefisien regresi Net Interest Margin adalah 0,532 dengan tingkat signifikansi sebesar 0,000 yang kurang dari 0,05 mengindikasikan bahwa $\mathrm{H}_{4}$ diterima. Hal ini mengindikasikan bahwa tinggi rendahnya nilai NIM tidak dapat empengaruhi kinerja keuangan. Hasil penelitian ini mengindikasikan bahwa semakin besar rasio NIM maka semakin meningkatnya pendapatan bunga atas aktiva produktif yang dikelola oleh bank 
sehingga kemungkinan bank dalam kondisi bermasalah semakin kecil. Begitu juga sebaliknya semakin kecil rasio NIM maka pendapatan bunga yang diperoleh bank berarti semakin kecil sehingga profitabilitas bank menurun dan kinerja keuangan bank juga akan menurun. Penjelasan diatas sejalan dengan hasil penelitian yang dilakukan oleh Sudiyanto \& Setyowati (2012) yang menjelaskan bahwa NIM (Net Interest Margin) berpengaruh terhadap kinerja keuangan.

Hipotesis kelima menyatakan bahwa Capital Adequacy Ratio berpengaruh positif dan signifikan pada kinerja keuangan. Berdasarkan hasil uji $t$ analisis regresi linier berganda pada Tabel 3, memperoleh nilai koefisien regresi Capital Adequacy Ratio sebesar 0,064 dengan tingkat signifikansi sebesar 0,015 yang kurang dari 0,05 mengindikasikan bahwa $\mathrm{H}_{5}$ diterima. Hasil penelitian ini menunjukkan bahwa besar kecilnya aspek permodalan atau capital yang diukur menggunakan Capital Adequacy Ratio (CAR) mampu memengaruhi kenaikan kinerja keuangan yang diproksikan dengan return on asset. Hasil penelitian ini sesuai dengan Teori agensi. Menurut Teori agensi, manajemen perusahaan lebih mengetahui bagaimana kondisi perusahaan dibandingkan dengan investor. Manajemen perusahaan perlu menerapkan Capital Adequacy Ratio untuk mencapai tujuan perusahaan. Rasio CAR yang semakin meningkat menunjukkan kemampuan bank yang semakin baik dalam mempertahankan kecukupan modalnya untuk menjaga kualitas bank agar tetap sehat sehingga meminimalisir terjadinya risiko sehingga dapat meningkatkan kinerja keuangan. Hasil penelitian ini sesuai dengan hasil penelitian yang ditemukan oleh Widati (2012), Olalekan \& Adeyinka (2013), Victoria \& Erawati (2015), Wantera \& Mertha (2015) menjelaskan bahwa CAR (Capital Adequacy Ratio) berpengaruh terhadap kinerja keuangan yang diukur dengan rasio ROA (Return On Asset). Hal ini disebabkan karena CAR memperlihatkan seberapa jauh seluruh aktiva bank yang mengandung risiko (kredit, penyertaan, surat berharga, tagihan pada bank lain) ikut dibiayai dari dana modal sendiri bank disamping memperoleh dana-dana dari sumber-sumber diluar bank, seperti dana masyarakat, pinjaman (utang), dan lain-lain. Dengan kata lain, capital adequacy ratio adalah rasio kinerja bank untuk mengukur kecukupan modal yang dimiliki bank untuk menunjang aktiva yang mengandung atau menghasilkan risiko, misalnya kredit yang diberikan. Dengan tingginya CAR maka kesempatan untuk menambah pendapatan akan semakin besar karena CAR memberi kepercayaan kepada Investor untuk menanamkan dananya sehingga akan menambah ROA dari pendapatan Bunga.

\section{SIMPULAN}

Berdasarkan analisis dan pembahasan diatas dapat disimpulkan Non Performing Loan berpengaruh negatif dan signifikan pada kinerja keuangan. Loan to Deposit Ratio dan Good Corporate Governance tidak berpengaruh dan signifikan. Net Interest Margin dan Capital Adequacy Ratio berpengaruh positif dan signifikan pada kinerja keuangan. Saran yang dapat diberikan melalui penelitian ini, yaitu: bagi manajemen perusahaan perbankan diharapkan memeperhatikan variabel independen yang memengaruhi kinerja keuangan, sehingga terhindar dari risikorisiko kinerja keuangan yang buruk. Bagi pihak yang berkepentingan diharapkan dapat memberikan tambahan informasi mengenai variabel-variabel dalam penelitian serta pertimbangan berinvestasi. Bagi peneliti selanjutnya diharapkan 
menambah atau memperluas variabel maupun lokasi dan juga rentan tahun sehingga menghasilkan data yang lebih akurat.

\section{REFERENSI}

Adebayo, M., Ibrahim, A. O. B., Yusuf, B., \& Ishmael. (2014). Good Corporate Governance and Organisational Performance: An Empirical Analysis. International Journal of Humanities and Social Science, 4(7), 170-178.

Astutik, P., \& Dzajuli, A. (2014). Pengaruh Tingkat Kesehatan Bank Menurut Risk Based Bank Rating terhadap Kinerja Keuangan (Studi pada Bank Umum Syariah Di Indonesia). Jurnal Fakultas Ekonomi Universitas Brawijaya, 3(1), 120.DOI: 10.15408/akt.v12i2.13189

Clemente, A. G., \& Labat, B. N. (2009). Corporate Governance Mechanisms and Voluntary Disclosure. International Journal of Accounting Information Systems, $5(1), 1-24$.

Crowe, K. (2009). Liquidity Risk Management-More Important Than Ever.

Dincer, H., Gencer, G., Orhan, N., \& Sahinbas, K. (2011). A Performance Evaluation of the Turkish Banking Sector After Global Crisis via CAMEL ratios. Procedia Social and Behavioral Sciences., 24(1), 1530-1545. doi:10.1016/j.sbspro.2011.09.051

Halisa, N. N., Purwanto, B., \& Maulana, T. N. A. (2017). Analisis Keagenan Pada Bank Yang Memiliki Anak Perusahaan Leasing. Jurnal Aplikasi Bisnis Dan Manajemen, 3(2), 278-289. DOI: 10.17358/JABM.3.2.278

Harsalim, J. P. (2017). Pengaruh Good Corporate Governance terhadap Kinerja Keuangan pada Peserta CGPI yang Terdaftar Di BEI Periode 2008-2013. Jurnal Akuntansi Universitas Surabaya, 6(2), 17-32.

Indrawati, V., \& Anan, E. (2014). Pengaruh Rasio-Rasio Keuangan Terhadap Kinerja Bank Di Indonesia (Studi Kasus pada Bank Pembangunan Daerah di Indonesia Periode 2008-2012). Jurnal STIEBBANK Yogyakarta, 5(2), 35-54.

Isramiarsyh, A. (2016). Analisis Pengaruh Risiko Kredit, CAR, BOPO, LDR Terhadap Profitabilitas Pada Beberapa Perusahaan Perbankan yang Terdaftar Di Bursa Efek Indonesia Periode 2010- 2014. Universitas Hasanudin Makasar.

Jensen, M. C., \& Meckling, William, H. (1976). Theory of the Firm: Managerial Behavior, Agency Costs and Ownership Structure. Journal of Financial Economics, 3(1), 82-137.

Kasmir. (2014). Bank dan Lembaga Keuangan Lainnya. Jakarta: PT. Raja Grafindo Persada.

Negara, I. P. A. A., \& Sujana, I. K. (2014). Pengaruh Capital Adequacy Ratio, Penyaluran Kredit dan Non Performing Loan pada Profitabilitas. E-Jurnal Akuntansi Universitas Udayana, 9(2), 325-339.

Olalekan, A., \& Adeyinka, S. (2013). Capital Adequacy and Banks' Profitability: an Empirical Evidence from Nigeria. American International Journal of Contemporary Research, 3(10), 87-93.

Olaoye, Festus Oladipupo Olarewaju, O. M. (2015). Determinants Of Deposit Money Banks Profitability In Nigeria. Kuwait Arabian Jurnal, 4(9), 11 - 18.

Olweny, T., \& Shipo, T. M. (2011). Effect of Banking Sectoral Factors on Profitability of Comeercial Banks in Kenya. Economics and Finance Review, 1(5), $1-30$. 
Porawouw, M. A., Pangemanan, S. S., \& Mekel, P. A. (2014). The Application Of Camel Model On Banks Listed In Indonesia Stock Exchange Period 2008 2010. Accounting Analysis Journal, 2(1), 192 - 200.

Putrianingsih, D. I., \& Yulianto, A. (2016). Pengaruh Non Performing Loan (NPL) dan Capital Adequacy Ratio (CAR) terhadap Profitabilitas. Management Analysis Journal, 5(2), 110-115. DOI 10.15294/MAJ.V5I2.7622

Satriawan, G. H. Y., \& Sudiartha, G. M. (2013). Pengaruh Car, Npl dan Ldr terhadap Profitabilitas pada Perusahaan Perbankan yang Terdaftar Di Bei Periode 2008-2011. E-Jurnal Manajemen Universitas Udayana, 2(11), 1449-1466.

Septiani, R., \& Lestari, P. V. (2016). Pengaruh NPL dan LDR terhadap Profitabilitas dengan CAR sebagai Variabel Mediasi pada PT BPR Pasarraya Kuta. E-Jurnal Manajemen Unud, 5(1), 293-324.

Srdan, M., \& Ognjen, R. (2014). Bank net interest margin related to risk, ownership and size: an exploratory study of the Serbian banking industry. Journal of Economic Research-Ekonomska Istrazivanja, 27(1), 134-154.DOI: 10.1080/1331677X.2014.952114

Sudiyanto, B., \& Setyowati, R. (2012). Pengaruh Bopo, Npl, Nim dan Car terhadap Kinerja Keuangan Bank(Studi pada Bank-Bank yang Listed di Bursa Efek Indonesia). Jurnal Dinamika Akuntansi, Keuangan Dan Perbankan, 1(1), 57-73.

Sugiantari, N. L. P., \& Dana, I. M. (2019). Pengaruh Loan To Deposit Ratio, Net Interest Margin Dan Inflasi Terhadap Profitabilitas. E-Jurnal Manajemen, 8(11), 6509-6532. DOI: https:// doi.org/10.24843/EJMUNUD.2019.v08.i11.p07

Suwandi, J., \& Oetomo, H. W. (2017). Pengaruh CAR, NPL, BOPO, dan LDR terhadap ROA pada BUSN Devisa. Jurnal Ilmu Dan Riset Manajemen, 6(7), 120.

Todorovic, I. (2013). Impact of Corporate Governance on Performance of Companies. Montenegrin Journal of Economic, 9(2), 47-53.

Victoria, N. P. L., \& Erawati, N. M. A. (2015). Pengaruh Rasio Keuangan dan Non Keuangan pada Kinerja Keuangan Perbankan. E-Jurnal Akuntansi Universitas Udayana, 13(2), 625-642.

Wantera, N. L. K. P. S. M., \& Mertha, I. M. (2015). Pengaruh Penerapan Corporate Governance, Dpk, Car dan Npl terhadap Profitabilitas Bank. E-Jurnal Akuntansi Universitas Udayana, 12(2), 154-171.

Widati, L. W. (2012). Analisis Pengaruh Camel terhadap Kinerja Perusahaan Perbankan yang Go Publik (Analysis The Influence Of Camel ( Car, Ppap, Der, Bopo, Ldr) Toward Performance Of Banking CompaniesIn Indonesia). Dinamika Akuntansi, Keuangan Dan Perbankan, 1(2), 105-119.

Widyastuti, S. K. (2017). Pengaruh Good Corporate Governance Terhadap Kinerja Keuangan Perusahaan (Studi Empiris Perusahaan Farmasi di Bursa Efek Indonesia Periode 2013 - 2016) (Vol. 01). Retrieved from http://www.albayan.ae

Yudiartini, D. A. S., \& Dharmadiaksa, I. B. (2016). Pengaruh Rasio Keuangan Terhadap Kinerja Keuangan Sektor Perbankan Di Bursa Efek Indonesia. EJurnal Akuntansi Fakultas Ekonomi Universitas Udayana, 14(2), 1183-1209. 